\title{
Investigating rural change. Legal access rights and changing lifestyles in rural mountain communities (Ligurian Apennines, Italy, 16th-21st centuries)
}

\section{Anna Maria Stagno}

To cite this article: Anna Maria Stagno (2019): Investigating rural change. Legal access rights and changing lifestyles in rural mountain communities (Ligurian Apennines, Italy, 16th-21st centuries), World Archaeology, DOI: 10.1080/00438243.2019.1674066

To link to this article: https://doi.org/10.1080/00438243.2019.1674066

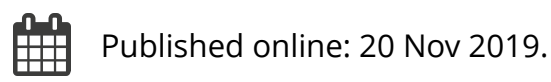

Submit your article to this journal ¿

山 Article views: 27

Q View related articles ¿

View Crossmark data ¿ 


\title{
Investigating rural change. Legal access rights and changing lifestyles in rural mountain communities (Ligurian Apennines, Italy, 16th-21st centuries)
}

\author{
Anna Maria Stagno iD \\ University of Genova, Genova, Italy
}

\begin{abstract}
The paper focuses on the strong relationship between changes in legal access rights to land, environmental resource management, as well as organization and lifestyles of past rural societies. The problem will be addressed through case studies derived from research projects in Southern Europe that rely on archaeological and historical research methods. The focus will be on the Ligurian Apennines in northwest Italy. I will demonstrate how changes in environmental resource management are recorded both inside and outside settlements, through archaeological and architectural study and through the landscape and environmental archaeology; I also examine how parallel changes in rural lifestyle can be tackled with these approaches. Particular attention will be paid to the period between the 18th and 20th centuries, when important transformations occurred related to access rights to common lands. The consequences of those changes played a leading role in the construction of rural landscapes that today are preserved as natural and cultural heritage.
\end{abstract}

\section{KEYWORDS}

Commons; management of environmental resources; rural societies; archaeology of architecture; landscape archaeology

«The landscape is the world as it is known to those who dwell herein, who inhabit its places and journey along the paths connecting them .... But in a landscape, each component enfolds within its essence the totality of its relations with each and every other. In short, whereas the order of nature is explicate, the order of the landscape is implicate» (Ingold 2000, 71).

\section{Introduction}

As generally acknowledged, rural areas have experienced profound changes during the last two centuries, which are fundamentally associated with the decrease of rural population overall, and the progressive reduction of agricultural workers. In Italy, more than $80 \%$ of the workforce was employed in agricultural jobs at the beginning of the nineteenth century, while at the present they account for just 3.8\%. At present, forests cover 10.4 million ha in Italy (34\%), but it was around 4 million ha in the 1930s (Agnoletti 2013). This difference is due to the abandonment of rural activities, which has had profound consequences on the landscape. Secondary woodlands have overgrown previously open areas such as grasslands, pastures and cultivated fields, which in turn have caused problems of hydrogeological stability, wildfires and loss of biodiversity. In Liguria alone, woodlands now make up $73 \%$ of the total surface, while employees in agriculture account for less than $2 \%$ of the population. ${ }^{1}$ 
These changes have often been defined as consequences of the 'agricultural revolution' or the 'agro-ecological transition' that has occurred in the course of the nineteenth century. This process is usually seen as being characterized by the progressive abolition of customary rights, the sale of common lands, the introduction of new crops (i.e. maize and potato), and to have emerged after the abolition of the feudal system and the mechanization of agriculture. These changes have sometimes been interpreted as the driving force of improvement in general. From a local perspective, however, the picture is rather more complicated and articulated, and generalization rapidly becomes difficult. For example, despite broad regional demographic growth, the mountain areas of eastern Liguria, which is the focus of this study, have seen a consistent depopulation after the mid-nineteenth century. Many of these migrants moved to coastal cities, but transatlantic migration was the most important process, which moreover usually involved entire families. It started out as a seasonal movement, but it had become permanent migration by the end of the century.

The role and significance of mountain areas in Europe has become a prominent topic of investigation for a number of interdisciplinary and multi-period projects that focus in particular on the environment and archaeological remains (e.g. Galop and Catto 2014; Collis, Pearce, and Nicolis 2016; Svensson and Costello 2018). Even if archaeologists have increasingly paid attention to the last two centuries (Horning and Palmer 2009), the profound changes that have affected mountain areas over this period have mostly been overlooked or underestimated, and only a few studies have explored the consequences of Capitalism and Improvement in rural areas (e.g. Mientjes, Pluciennik, and Giannitrapani 2002). The well-studied British 'enclosure' process stands out as the exception that proves the rule (e.g. Dalglish 2003; Tarlow 2007). Even so, it is perhaps the Mediterranean mountains that are beginning to receive more attention, as diachronic research has begun to examine developments from prehistory to the present. A good case in point are the longterm projects in the Natural Parks of the Pyrenees (Le Couédic et al. 2015), in the French Maritime Alps (Walsh and Mocci 2016), and in North Italy in the mountains of the Trentino (Angelucci et al. 2013) and the Ligurian Apennines (Cevasco 2013). A parallel and partially intersecting development that has helped to draw attention to the archaeology of recent periods is the integration of ethnographic and archaeological research, including fieldwork, to study pastoralism, agriculture and landscape more broadly (Rendu et al. 2016 on the French Pyrenees; Mientjes 2008 on Sardinia; Forbes 2008 on Greece; Carrer 2017 on the Maritime Alps).

In this paper, I highlight two key phenomena in particular that played out in Western Europe over the course of the nineteenth century, namely the increasing prominence of sedentary ranching, which gradually replaced transhumant animal husbandry from the eighteenth century onwards, and the weakening of multiple-resource management systems, which were closely linked to customary access rights (Moreno 1990; Kirby and Watkins 1998). Where the same plot of land has traditionally been used for pasture, collecting wood and temporary cultivation, the nineteenth century witnessed an ever-increasing tendency towards specialized land use, which involved the exclusive dedication of land to agriculture, or animal husbandry or forestry. The consequences include the drastic reduction throughout Europe of tree-covered pastures, which used to characterize European mountains (Grove and Rackham 2001; Rotherham 2013; Agnoletti and Emanueli 2016), and the almost complete disappearance of temporary cultivation and the vegetation management techniques that involved fire (Viader and Rendu 2014 for references).

The research discussed in this paper comes out of several multidisciplinary projects in the eastern Ligurian Apennines (Figure 1) developed in association with the Laboratory of Archaeology and Environmental History (LASA) of the University of Genova (Italy). I will outline the different responses of two rural communities, at Perlezzi and Ventarola in the 


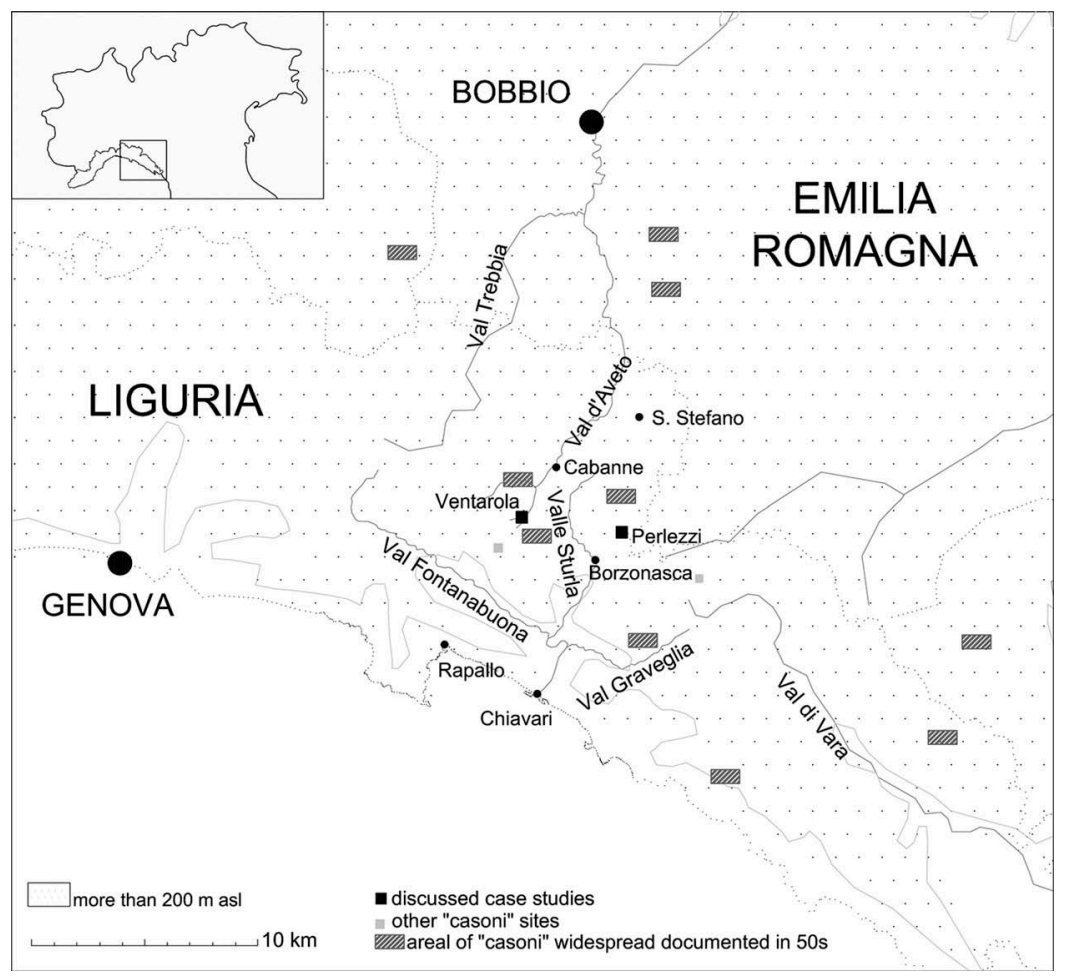

Figure 1. Map of the Ligurian Apennines (NW Italy), showing the location of the villages of Ventarola and Perlezzi (from Stagno 2016, p. 74, fig. 6.1 modified).

neighbouring Sturla and Aveto valleys, to wider economic and political changes, and how archaeological evidence adds to our understanding of these different local developments. In the first case-study on Ventarola, I adopt a geographical-historical perspective, in which rural houses are seen as a 'functional materialization of specific agricultural systems' (Gambi 1976, 479). I thus investigate buildings and, in particular, changes in functional spaces like barns and sheds, to reconstruct changes in resource management. I then compare these interpretations to demographic sources and a more detailed analysis of spatial organization in Ventarola. In the second case-study of Perlezzi, I use archaeological survey evidence to document the material and technical consequences of a conflict over access rights and the ownership of water for irrigation, including the commons where the water was sourced. These insights enable me to highlight the close relationship between collectively held properties and privately owned ones, and between agriculture and animal husbandry. In this way, I hope to bring out the relationships between occupied and non-occupied spaces that may not be readily evident, but that can be traced through comparison of material evidence and documentary sources, in order to come to a more articulated and discontinuous reconstruction of the transformations of local space and social organization. This allows me to explore the different trajectories of landscape changes and economic development, and of the organization of collective access to and ownership of land, that the two hamlets followed during a period of allegedly uniform rural transformations. 
Both study areas are part of the Parco Naturale Regionale dell'Aveto and are thus preserved as natural heritage, which invites reflection on collective resource and heritage management.

\section{Studying landscape and environment}

My research methods are based on the so-called 'Environmental Resources Archaeology' that has been developed over the past 30 years by the Laboratory of Environmental Archaeology and History (LASA) at the University of Genova. During the 1970s and '80s, a multidisciplinary approach emerged from historical and geographical work on rural population dynamics (Moreno 1990) to study environmental knowledge in broad terms. Particular attention was given to the ways in which activities and practices change over time, and how they relate to social processes. This approach was subsequently enriched by perspectives and methodologies in medieval archaeology (Quaini and Moreno 1973), environmental history as developed by Oliver Rackham and the Historical Ecology Research Group since the 1960s (Rackham 1976), Italian social microhistory and its focus on the local dimensions of historical processes (Grendi 1993), and, finally, environmental archaeology (Maggi, Montanari, and Moreno 2002).

It is important to underline that both English historical ecology and Italian medieval archaeology and micro-history explicitly recognize intellectual debt to English local history as pioneered by William George Hoskins and Maurice Beresford. At the same time, there remains an important difference between the archaeology of environmental resources on the one hand, and on the other hand the broadly comparable approaches of 'historic landscape' characterization (Clark, Darlington, and Fairclough 2004; Fairclough and Wigley 2006; Turner 2006), and 'anthropological' historical ecology as inspired by the French Annales school (Meyer and Crumley 2011). The main interest of the approach of the environmental resources archaeology is not the landscape or environmental dynamics, but rather the social processes as they relate to specific configurations of the landscape ('individual landscapes'), and to the effects of the abandonment of environmental resource management. Further differences are a critical approach to the process of 'heritagisation' and the concept of landscape, and attention to the local and contemporary relevance of historical research, as inspired by the 'political approach' of the historical geography. It is, in fact, the local dimension of this research that makes it possible to highlight the role of local actors and social groups in the construction of the natural and cultural heritage of rural areas, and to formulate proposals to promote the local management of historical and environmental resources (Moneta and Parola 2014).

Archaeological research of environmental resources is presently mostly focused on two complementary perspectives that are both based on combinations of fieldwork and documentary research to connect specific sites to and situate them within wider study areas. The first one aims to reconstruct the historical processes of biodiversification through historical-ecological and environmentalarchaeological investigations (Cevasco 2007), while the second one scrutinizes the relationships between resource management practices and population histories through archaeological and archival (demographic, cartographic, jurisdictional) evidence (Stagno 2018). There are clearly many similarities and interfaces with historical archaeology, in particular for the central problem of how to compare different sources and procedures (Andrén 1998). Of crucial significance for such research is, in my view, to make clear how sources are constructed, read and interrogated, and to be aware that each point of view will profoundly influence the data gathered and the ensuing interpretations of the past (Moreno 1976; Gilchrist 2009). In this paper, I concentrate on identifying resource management practices and their transformations, and I explore how these reflect and provide insight into other 
aspects of life in past rural societies. I give particular attention to the meaning of practices for claiming access rights to land, because these were of fundamental importance to the social organization of the ancien régime (Thompson 1993; see also Relaki and Catapoti 2013).

\section{Study area}

At the heart of this study are two adjacent valleys in the Ligurian Apennines known as Val d'Aveto and Valle Sturla. The eastern reaches of the Ligurian Apennines, where these valleys are located, were occupied until at least the Middle Ages by scattered settlements and large swathes of common land, which were connected through vertical forms of mountain exploitation (Moreno and Raggio 1990). The settlements are known as ville (villages) in post-medieval archival sources (Raggio [1990] 2018). The two hamlets, which were the focus of research in the two valleys are Ventarola (Rezzoaglio, GE) and Perlezzi (Borzonasca, GE).

Ventarola is a mountain hamlet at about $845 \mathrm{~m}$ a.s.I. in the upper Aveto valley, which today consists of seven houses, with only one of them still inhabited. It was part of the Doria family fiefdom until the end of the feudal system in 1797. Perlezzi is located at 400-600 m a.s.l. in the Valle Sturla, and was part of the Genovese Republic, where it fell under the jurisdiction of the capitanato of Chiavari. After 1814, both areas were incorporated into the Kingdom of Sardinia, where they, respectively, resorted under the mandamento (district) of Santo Stefano d'Aveto and of Borzonasca. Most of the ville were associated with a dominant kin group (Raggio [1990] 2018), and demographic and archival study has identified Ventarola as the villa of the Biggio kin group, and Perlezzi as that of the Massa as late as the end of 19th c.

\section{From multiple to 'specialized' rural organization: Ventarola between the fifteenth and twenty-first centuries}

Ventarola first became an object of study in 2005, when archaeological fieldwork was carried out in association with the restoration of one of the buildings in the hamlet, which was to be converted into a hiking refuge for the Aveto Regional Natural Park. Most of the work went into reconstructing the functional organization of the productive spaces both inside and outside the hamlet between the fifteenth and the twenty-first century. By comparing the stratigraphic discontinuities in the subsoil and the architecture of the excavated areas and the standing buildings of the hamlet, with the historical demography of Ventarola, alongside the cartographic and textual evidence of land use on the mountain slopes linked to the hamlet, the relationships between the settlement and the organization of rural spaces around the village could be studied (Stagno 2018).

Analysing the material differences between the buildings shed light on socio-economic stratification of the Ventarola community within the Biggio kin group. The transformations of the settlement and the road network showed that between the seventeenth century and the first half of the nineteenth century, Ventarola was transformed from a scattered settlement (1630) into a linear-nucleated settlement (Figure 2). In the second half of the nineteenth century, the settlement lost its linear alignment, as buildings were constructed into all directions, which suggests that the road network that traversed Ventarola had lost much of its importance. Two of the oldest buildings in Ventarola have been interpreted as stables for mules, which points to Ventarola's role as an important access point to the upper Aveto Valley within a network of commercial and transhumance routes. These connected Rapallo and Chiavari to towns in the Po valley via major centres like Piacenza and Bobbio, as well as to the winter pastures of the Riviera di Levante and the mountain summer pastures of the Po valley (Figure 3). Based on detailed agreements of 

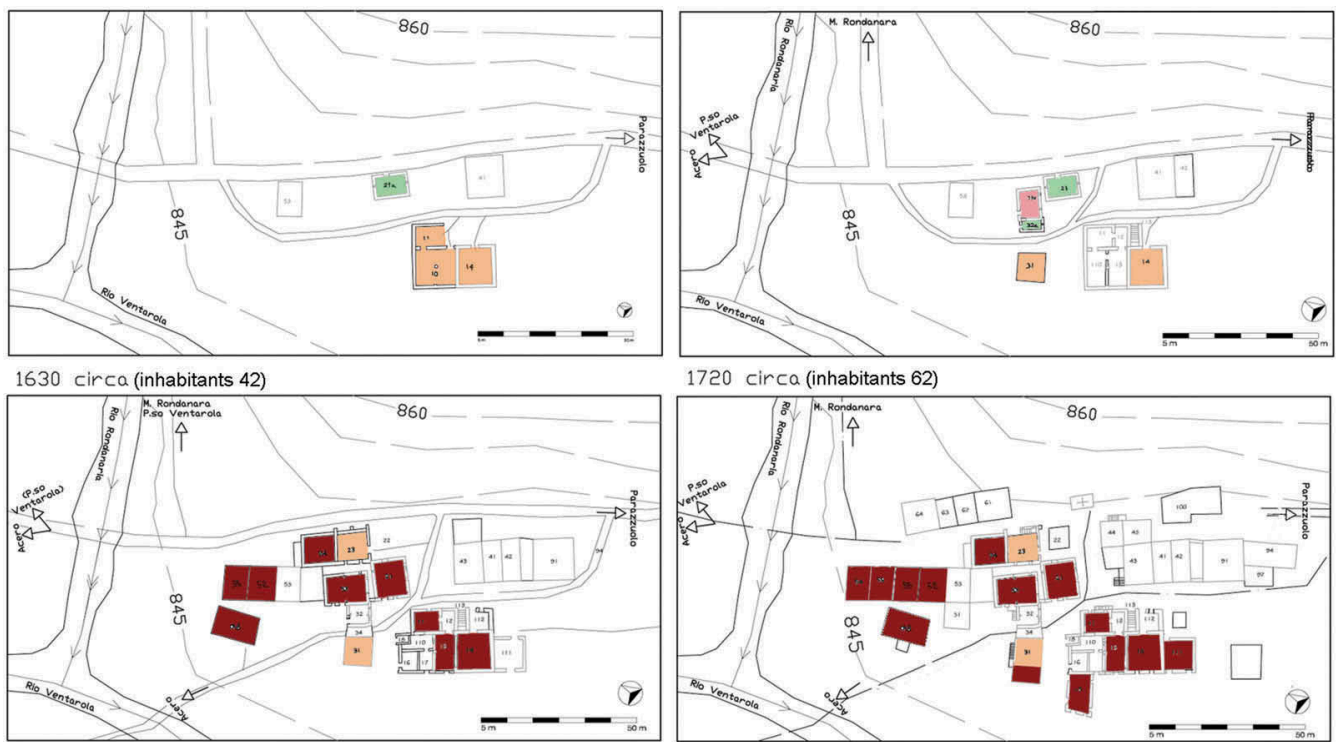

1720 circa (inhabitants 62)

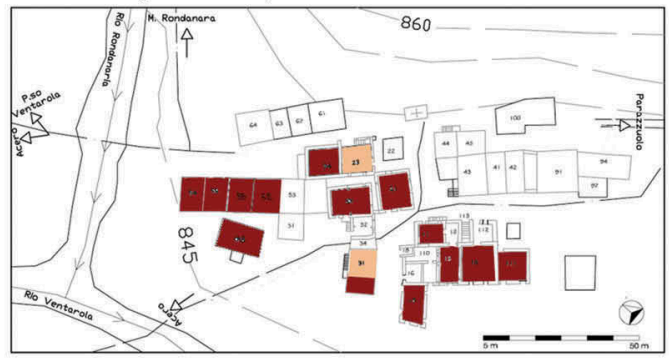

1820 circa (inhabitants 105 )

Legend: "stable " sheds for shep or goats "byres

1940 circa (inhabitants 40; in this period some cascin-ne also used to host mules cascin-ne used for collecting wood).

Figure 2. Plans of the village of Ventarola, showing how its layout, locations of functions, and roads changed between ca. 1630 and ca. 1940 (Stagno 2018, 67; fig. 2.24, modified).

reciprocity, so-called soccida contracts, in the summer sheep went up from Rapallo to the imperial estates in the Aveto and Trebbia valleys, while in winter animals from those areas went down to the coast through the Fontanabuona valley. This organization, well-recorded for the ancien régime, gradually disappeared in the course of the nineteenth century (Stagno 2018). Ventarola was moreover also part of a system of shorter-distance connections, which involved the ville, with which Ventarola shared the collective use of land (the so-called comunaglie), and those of the parish of Cabanne, as well as some ville outside the fief of Santo Stefano d'Aveto.

The impact of a trunk road network that was suitable for carriages, which had been expanded since the second decade of the nineteenth century by the Kingdom of Sardinia, is visible in Ventarola in the disarticulation of the settlement organization. The prominence of the new trunk roads and the abolition of the feudal system undermined local control of commercial trade routes and reduced the commercial role of most of the ville of the older road network (Figure 3). Archival documents show that the number of inhabitants began to decline around this time as well.

The same archival sources also show that already in the earlier nineteenth century families were becoming larger and more complex, as is indeed evident in the increased size of domestic buildings, and also demonstrated by the architectural study. This one also showed that many transformations recorded from the fifteenth century onwards may be related to changes in environmental resource management. In particular, analysis of room functions and sizes has highlighted the importance of animal husbandry (sheds and hay barns), and has made it clear that domestic and livestock-related spaces were increasingly separated after the eighteenth century, when buildings were constructed or converted for housing and feeding animals: the so-called cascin-ne, which are sheds with hay barns on the first floor, date to this period (Stagno 2018, 60-62).

Starting in the nineteenth century, we also see new livestock sheds that have proper windows instead of the traditional slits, and that are equipped with sewage drainage systems. The first and 


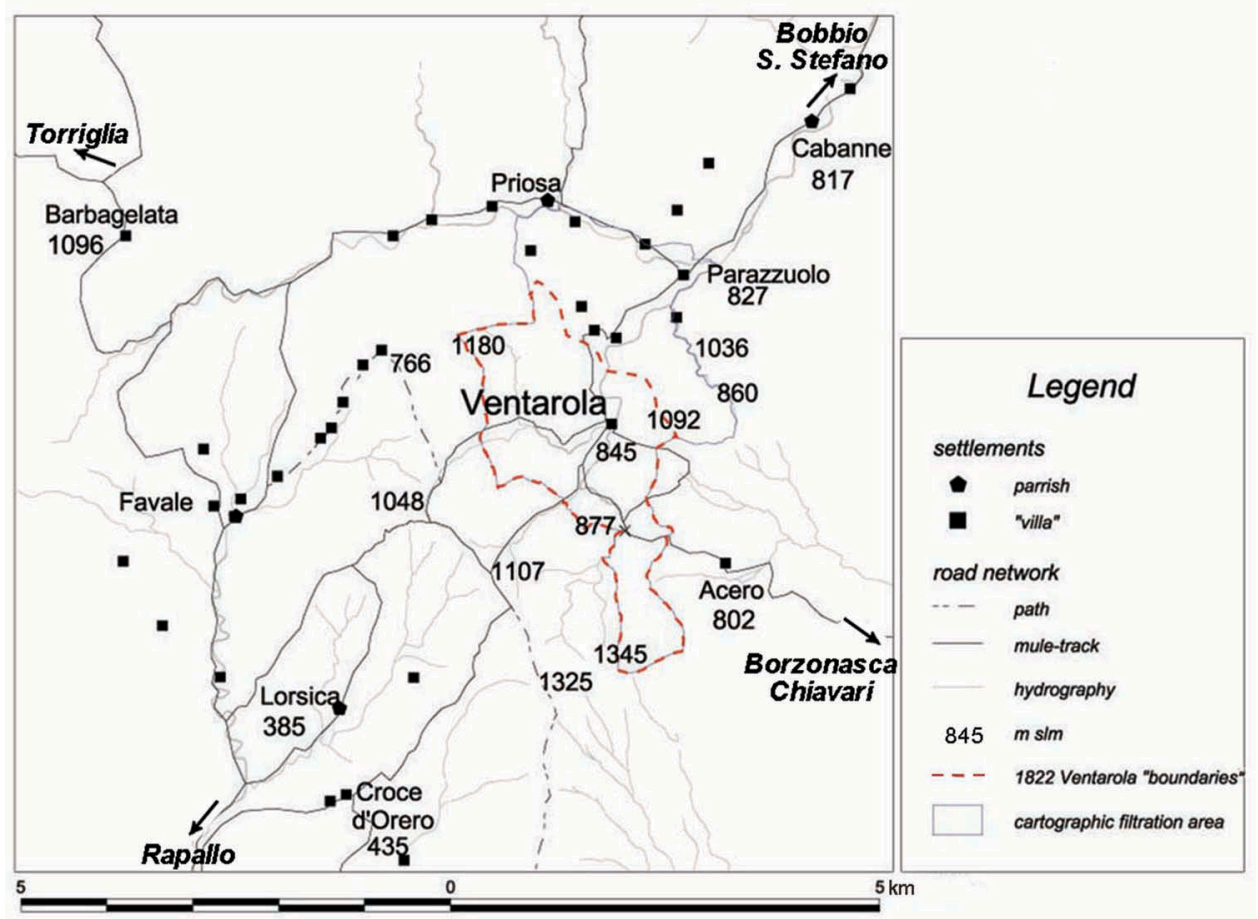

Figure 3. Road network and settlement pattern of the high Aveto valley at 1820 (Stagno 2018, 77; fig. 2.38 modified).

sometimes second floors have window openings of considerable size, compatible with their use as hay barns and storage buildings. Throughout the nineteenth century, new byres were also built in the south-eastern part of Ventarola in order to facilitate the direct use of liquid manure fertilizing the vegetable gardens.

Between the mid-nineteenth century and the first decades of the twentieth century, the size and numbers of cascin-ne increased considerably. This development was unrelated to demographic growth, as the population of Ventarola started to decline in 1869, until it reached today's two inhabitants. These changes may instead be explained by a shift from transhumant sheep-goat breeding to resident bovine husbandry, which requires larger livestock sheds. The new structures are moreover suitable to keeping cattle indoors throughout winter, unlike the older structures, which at best could only occasionally shelter sheep or goat. It is also worth noting that these new cattle byres replaced older structures with remarkably large doors, that were more than $1.60 \mathrm{~m}$ wide, and presumably held mules and carts for loads.

Another feature of these architectural changes was the management of local environmental resources, that during this period shifted from multiple uses to a single-specialized one (Moreno 1990). This shift has been documented between the eighteenth and twentieth centuries, using sources such as a statistical inventory of woodlands (Consegne dei boschi) in the 1820s and cartographic maps commissioned by the Kingdom of Sardinia. ${ }^{2}$ Another set of maps was created a century earlier in the 1720s during a legal dispute between the House of Doria and its subjects. These have shown that land use in the eighteenth and early nineteenth century was complex and characterized by a highly specialized cycle, in which alder played a key role because of its fertilizing 
properties - and for this reason it was named alnocoltura or alder coppice system, when it was reconstructed through archival research (Moreno et al. 1998; Cevasco 2007). This cycle included forestry, grazing, and temporary cultivation on a single plot of land mostly covered by alder. Archival sources label this campeggiare ('making fields') or roncare (preparing land for cultivation through controlled fire).

Focusing specifically on Ventarola, historical maps of the eighteenth and nineteenth centuries show that rural organization at and around Ventarola was defined by the notions of beni domestici ('domestic lands') and terre salvatiche ('wild lands'). The former were permanently cultivated, for instance as vegetable gardens, and were not open to collective use - although exceptions were made for grazing. The latter were mostly covered with scattered trees and used in a variety of ways as described above. The terre salvatiche of Ventarola could be privately held or owned jointly (as common land) by a single kin group, all inhabitants of the village, or they could be shared with neighbouring settlements.

Pollen analysis of a stratified soil sample from an area historically known to have been managed through alnocoltura, has attested the medieval origins of the system, which appears to have been developed in areas previously used as wooded-meadow pastures. It also shows that the combined presence of alder, pastoral indicators and cereal pollen can be traced throughout the Middle Ages until the nineteenth century (Molinari and Montanari 2016). Historical maps show that the most important changes in vegetation and land use occurred between the nineteenth and twentieth centuries (Figure 4). The map of the 1820s shows that the slopes were largely covered by scattered trees around that time, while later ones show increasing areas of permanent grassland and pasture. In other words, these maps record the shift from multiple management of environmental resources (agricultural, forestry and pastoral) to a specialized system. The increased presence of open areas for pasture and making hay in 1936 may, for instance, be correlated with the higher number of hay barns in the hamlet, which is in turn associated with an expansion of cattle breeding and recorded by the archaeological investigation. At the same time, the presence of terraces around Ventarola suggests an intensification of permanent cultivation. It is interesting to note that the progressive reduction of woodland, alongside an increase in cattle breeding and intensive agriculture, is matched by a rather abrupt decrease of population, as the number of inhabitants of the Cabanne parish had decreased by 1928 to reach the same level as in the first half of the eighteenth century (around 600 inhabitants, down from 1025 in 1869). These data thus call into question the widely held assumption that deforestation and demographic pressure go hand in hand (Vecchio, Piussi, and Armiero 2002, 170-78). Finally, in 1999, maps show a post-agricultural situation, in which woodlands dominate as a consequence of the abandonment of agro-forestry-pastoral practices.

It thus seems plausible to conclude that the intensification of farming and animal husbandry activities in Ventarola during the second half of the nineteenth century and the early decades of the twentieth century represent the result of its diminished commercial role in long-distance social and geographical relationships. This transition to local scale relationships is also reflected in the buildings of the village. Prior to the nineteenth century, lintels of older doors and arches suggest that Ventarola was part of the seasonal routes that itinerant artisans known as maestri lombardi took through the Ligurian and Po valleys. After the mid-nineteenth century, however, the buildings give the impression to have been built by local workers from Ventarola.

As argued above, the success of sedentary cattle breeding in Ventarola during the nineteenth century is associated with an increase of permanent grasslands and the progressive disappearance of multiple environmental resource management, and above all of scattered trees in favour of spaces permanently devoted to (terraced) agricultural fields, grassland, 

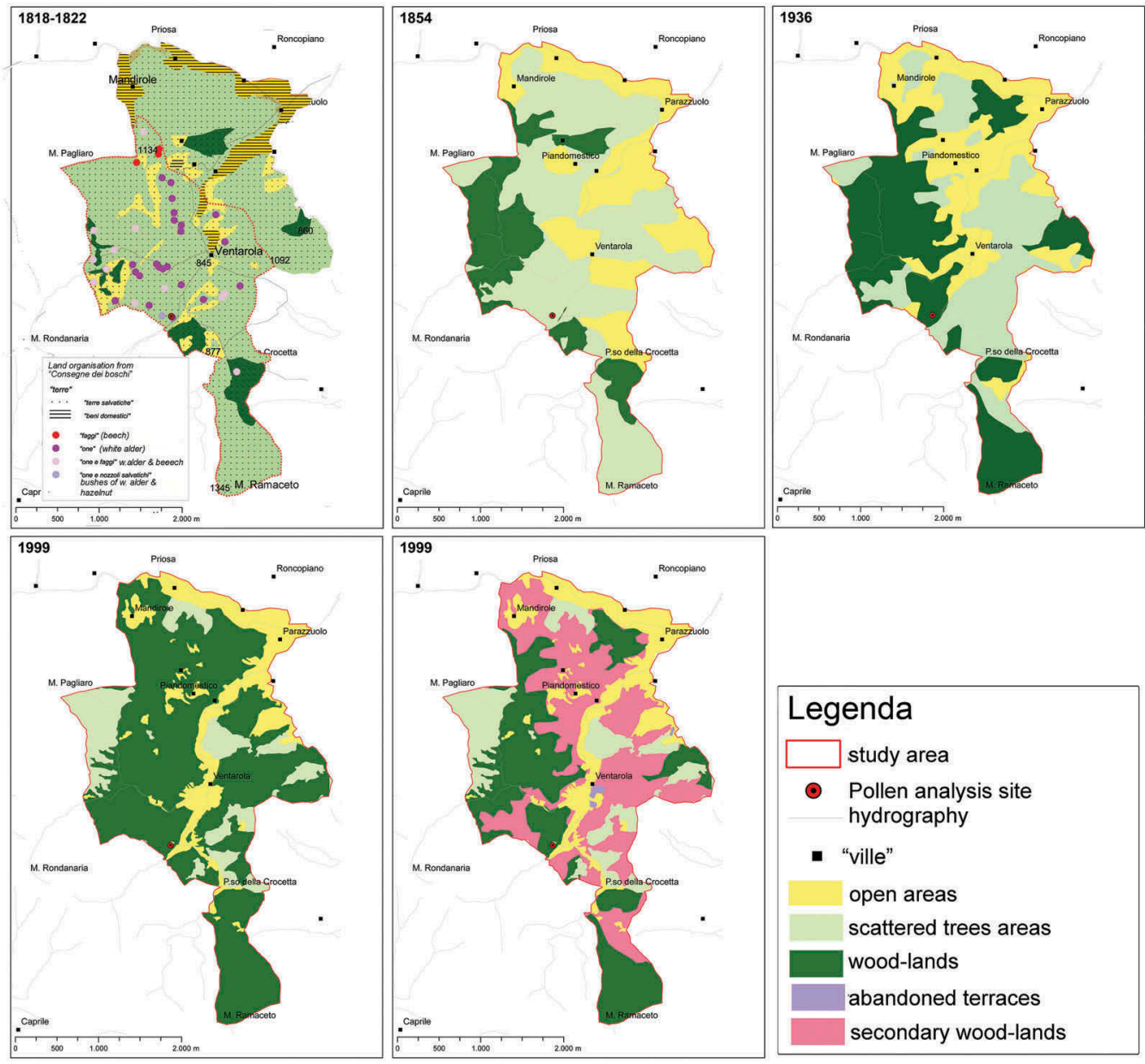

Figure 4. Plans showing the transformations of vegetation cover as deduced from cartographic analysis (1820-1999; Stagno 2018, 85-87; figs. 2.41, 2.44 modified).

pasture or woodland. This may largely be ascribed to the radical reforms that the Savoys imposed on the management of woodland and 'wild' areas (incolti) in the nineteenth century. In keeping with agronomic thinking at that time and a new approach to land taxes, the regulations adopted after 1815, and especially after 1870, when the first law on forestry was introduced in Italy, privileged monocultures over customary use of shared land and common resources (Stagno 2018, 88-93; Moreno 1990, 54-56; 222). I suggest that these transformations in the landscape of Ventarola correspond to changes in the taskscapes of its inhabitants, which is the landscape created by the repetition of daily tasks (Ingold 2000), and their organization of labour. The sedentarization of animal husbandry, for instance, as recorded by the increased the number of byres and hay barns, suggests that these work activities became sedentary and were no longer rooted in cycles of seasonal migration, which integrated agro-forestry-pastoral practices with other activities, such as trade and seasonal labour outside Ventarola. The resulting narrow economic basis likely led to a loss of inhabitants. The success of potato and maize crops, which require work in periods of the year previously not devoted to 
agricultural work, and the increased control of the Sardinian Kingdom over seasonal migration during the nineteenth century, no doubt accelerated these changes (Salvi 1981). Even if these changes initially improved food security, which in turn probably allowed families to become larger, other developments in the nineteenth century made families vulnerable, because they became dependent on a single source of income (agriculture), whereas agriculture had previously always been seasonal and supplemented by opportunities of seasonal labour elsewhere, for instance in France, the Po Valley and Genova, and others created by the commercial routes. This change explains the process of depopulation from the second half of the nineteenth century.

Along with the disappearance of collective forms of environmental resource management, lifestyles in Ventarola became more individualized as a result. Before the nineteenth century, there was no evidence of kitchens or family ovens, which suggests a reliance on common ovens, but by the beginning of the twentieth-century bread ovens within a single home and masonry kitchens started to appear.

\section{From pastures to terraces: moving seasonal settlements and work organization in Perlezzi}

Perlezzi is located in the Sturla valley, in an area characterized by a network of irrigation channels and agricultural terraces. The cultivation of chestnuts and of vegetables, which is typical of the Apennines, is associated with the reshaping of the mountain slopes with terraces and the adoption of a complex irrigation system. The higher reaches of the mountains are by contrast defined by extensive pastures, wetlands and beech woodlands. Cultivation on irrigated terraces remains common in this area and has been cited as evidence of a more widespread occurrence of irrigation in the past, not unlike elsewhere in Europe (e.g. Martín Civantos 2011).

A peculiar characteristic of this landscape are the relationships between the irrigation network and the commons (once called comunaglie, today usually referred to as beni frazionali) in the upper part of the valley, where the irrigation channels originate, and the irrigated terraces further down. On the lower slopes, between approximately 500 and $800 \mathrm{~m}$ a.s.l., there are vast-terraced areas, which in most cases are located close to settlements. The terraces around Perlezzi are used for vegetable gardens, and they are lined by rows of vines of the variety 'dolcetto nero', offering a rare surviving example of this type of arrangement. The continued use of the irrigation system has ensured the survival of the original structure of the terraces and channels. As a result, it is still possible to identify the various phases of development and to associate them with the gradual development of settlements.

The archival evidence on one of the many controversies over use and ownership of water, the irrigation channels and the commons of multiple villages sheds light on the ways in which local social groups claimed their rights, and how the Genoese Republic proposed to resolve such disputes over common land. More specifically, by comparing a map created as part of these arguments, the Tipo geometrico of Domenico Carbonara of 1752, to the results of the archaeological investigations in and around Perlezzi, it becomes clear how the commons were organized, and how the environment of Perlezzi was managed in the eighteenth century (Stagno and Tigrino 2012; Stagno 2018).

The archaeological survey around Perlezzi shows the various stages of the terraces and their construction processes. For each phase, the terraces and associated irrigation channels were built at the same time, and cartographic data indicate that such building activities peaked in the eighteenth century. I have therefore interpreted the legal controversies of that time as a result of a new and 
increased demand for water when the mountain slopes around the villages were brought into cultivation (Stagno 2018; Stagno and Tigrino 2012). In the case of Perlezzi, this process seems to have been related to demographic growth, even if elsewhere specific families took the lead in agricultural expansion. This was, for instance, the case in the nearby village of Caroso, where documents about payment for irrigation channels survive.

This colonization also had a direct effect on the use of the commons, as documented by the changes in the location of seasonal settlements (locally named casoni), which were reconstructed from archaeological and archival data (Figure 5; Stagno 2016).

The aforementioned map shows casoni at different locations, namely on common land in the mountains at a distance of 6-7 km from the hamlet, and on properties close to the irrigation channels. The former casoni are described as collapsed due to abandonment ('demolished by time'), while the latter are marked as being in use.

The archaeological survey of the commons, however, recorded no remains of earlier structures around Perlezzi, even if there was evidence of eighteenth-century land use, such as the wet meadow-pasture system and associated temporary sites. This suggests that casoni were built with perishable materials and disappeared without leaving traces, especially as elsewhere post-medieval and medieval seasonal settlements in the mountains can be, and have been, recognized by surveys (Le Couédic et al. 2015).

Around Perlezzi, however, surveys recorded an important number of stone-built casoni near the bottom of the commons and at the top of terraces where the irrigation channel delivers the water. These buildings generally consist of two floors, one devoted to livestock and the other one used as a hay-barn, as is evident from the size of doors and windows and the presence of feeders on the ground floor. While some of these casoni may be dated to the first half of the eighteenth century on the basis of the types of door-lintels used, many were built later. The implication is that the number of casoni on the terraced slopes gradually increased during the eighteenth and the nineteenth century, presumably in tandem with the expansion of terracing on the slopes.

These findings suggest that the location of casoni shifted during the eighteenth century from the commons to the terraces. Both this shift and the increase in number may be ascribed to a change in function of these buildings in the wake of the fundamental reorganization of the local, shortdistance cattle transhumance system (monticazione). Sixteenth and seventeenth-century archival sources suggest that casoni were located on common land and used for local animal husbandry as

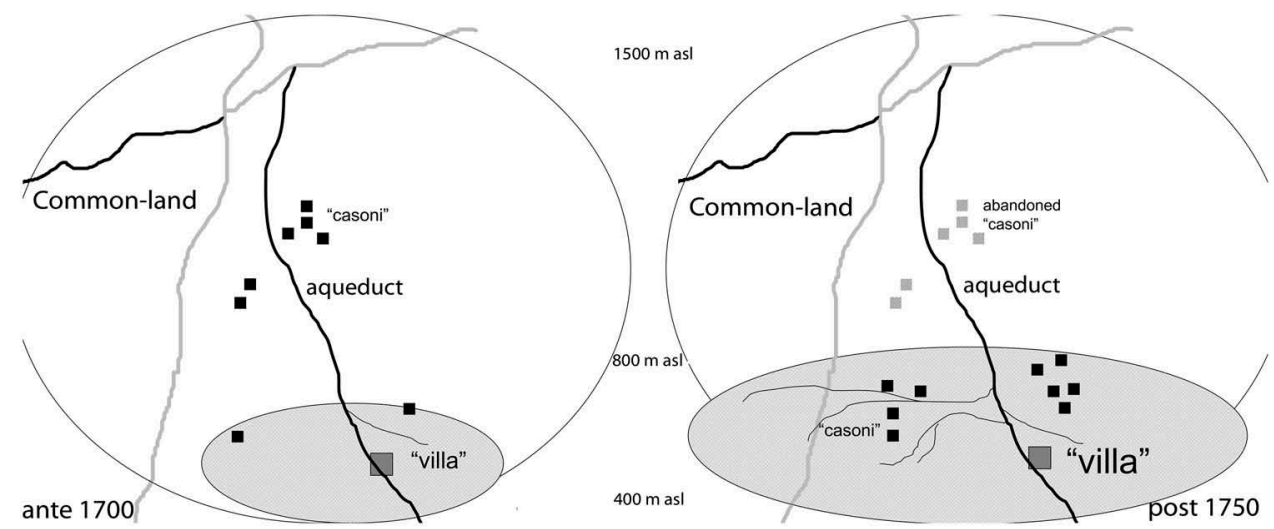

Figure 5. Sketch of the location models of casoni before and after 1700-1750, derived from the Perlezzi case study (Stagno 2016, 76; fig. 6.3). 
temporary shelters for animals and shepherds, and possibly as temporary barns for hay collected from the commons (Moreno 1990). Casoni were thus an integral part of the monticazione system that took cattle to the mountain pastures in the summer and kept them in stables within the settlements over the winter (Moreno and Raggio 1990). During these centuries the system coexisted with the larger flows of long-distance transhumant sheep.

At Perlezzi, I have found that the monticazione system was completely reorganized in the eighteenth century as a result of the expansion of terraced agriculture and chest-nut cultivation. The features and locations recorded by the archaeological survey indicate that eighteenth and nineteenth-century casoni were also used for agricultural activities on the terraces, which served as vegetable gardens, and to produce wheat, hay and chestnuts. Local cattle and shepherds did not spend the night on the commons, as the former were kept in the byres nearby the terraces, while the latter returned to the hamlet every day. The construction of new casoni close to the terraces moreover facilitated manuring of the terraced fields, which in turn extended the period in which animals could be kept outdoors and close to the village - San Martin's day on November 11 became the traditional reference date for taking cattle inside the byres. In the nineteenth century, the construction of cattle enclosures, as for instance at the site of Case del Fei (Figure 6), also served to collect manure, which provides further evidence of the close connection between the reorganization of the monticazione system and the agricultural activities. The increased number of casoni in the nineteenth century thus shows that local animal husbandry became of prime importance, as long-distance transhumance virtually disappeared.

Similar locational shifts of casoni have been recorded for the eighteenth and nineteenth centuries in eastern Liguria, which suggests that the developments at Perlezzi were not an isolated phenomenon (Stagno 2016). This form of monticazione has been documented until the 1950s, as it matched descriptions by people still using the casoni around that time.

Unlike at Ventarola, however, these changes did not modify, but on the contrary increased, the sharing of spaces and forms of collective organization: casoni, for example, invariably consist of small groups of two or more buildings owned by different people. This is particularly evident at Casoni detti li Fei, for which the Tipo geometrico map records below each building the name of the holder. This also suggests the co-participation of the same people in the construction of that part of the terraces and irrigation channel, as is indeed attested by archival sources. Since the construction of terraces and an irrigation system moreover require collective labour, even if the extent of the commons was reduced in the process, the irrigation works and water-sharing arrangements ended up increasing interaction and joint work among the area's inhabitants. This development finds an interesting parallel in the occupation and appropriation of common land by local communities in the Middle Ages, as has for
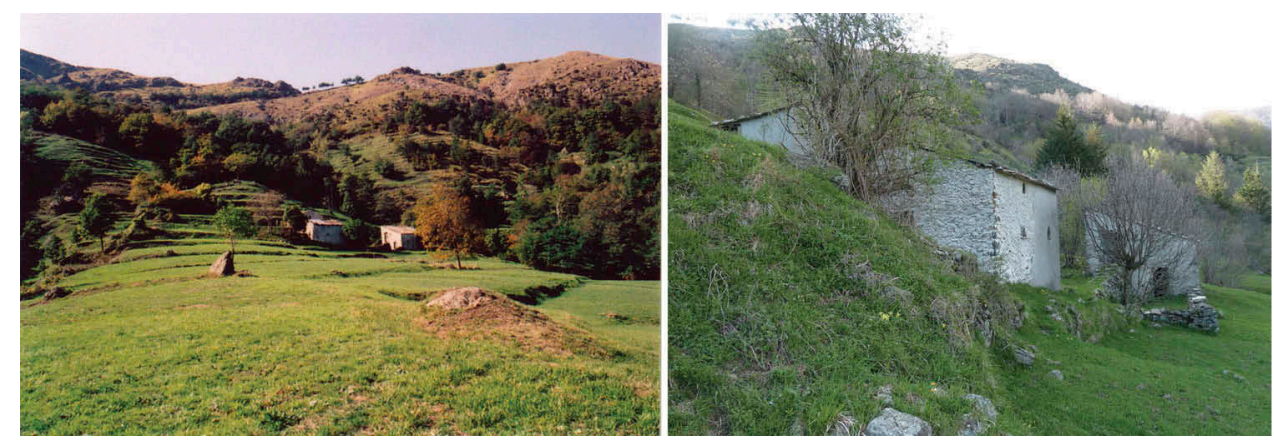

Figure 6. Two views of Perlezzi, showing terraces and casoni at Case del Fei, and a detail of the latter (left), and an enclosure for the collection of manure of the 19th casone (right: photos A. M. Stagno, April 2009, 2013). 
instance been shown for the French Pyrenees (Rendu 2003; Bille, Conesa, and Viader 2007). Appropriations of parts of the commons involved several families or even the entire community, which seems to match how the terraces in Perlezzi and the neighbouring villages were constructed.

The irrigation system at Perlezzi is in excellent condition, and thus shows very well how the main canal splits into an increasingly dense network through a series of stone conducts to bring water to each terrace, and then to each individual chestnut tree through ditches dug in the ground. The pastures of Perlezzi continue to be managed collectively thanks to the Comitato di Gestione dei Beni Frazionali, which rents out the pastures and shelters for free to the Consorzio di Miglioramento Zootecnico ('consortium for the improvement of animal husbandry'). The latter is made up of the livestock owners of Perlezzi and nearby villages. Thanks to the preservation of the mountain pastures, the spread of woodland was prevented. In the areas above $800 \mathrm{~m}$ a.s.l., which are mainly large open spaces, goat and cattle still graze freely. Irrigation management, which in the past was linked to hereditary rights, is since the 1960s given over to the Consorzio di Miglioramento Fondiario, which any landowner in Perlezzi can join for a fee (Stagno and Tigrino 2012; Stagno 2018).

\section{Discussion and conclusions}

In this paper, I have adopted a qualitative rather than a quantitative approach in order to explore specific historical processes and social relationships by observing them from different points of view and through different sources. The two case studies accordingly address the same process, which is that of the progressive growth and prominence of cattle breeding from the mid-eighteenth century onwards, and its intensification in the nineteenth century at the expense of long-distance transhumance. These broad developments are well known in general terms from Ligurian Apennines (Moreno 1990) and from Italy and Europe more broadly (Vecchio, Piussi, and Armiero 2002).

By focusing on these case studies, I have been able to home in on local details and specific circumstances, which are all too often obscured by broad overviews of general processes. I have outlined the relationships between the changes in environmental resource management, access rights and lifestyle, and to appreciate the notable differences between the villages under study. At Ventarola, the rise of cattle breeding and terracing coincided with the demise of the village as a distribution centre in local commercial networks. In Perlezzi, the increased importance of cattle breeding coincided instead with the construction of irrigation systems and a turn to chestnut exploitation, which reveals the broad basis of the local economy in this village. The production and distribution of chestnuts and later hazelnuts moreover encouraged villagers into engage with broader commercial networks (Vaccarezza 2011). As a result, Perlezzi still boasts over one hundred inhabitants today, while Ventorala is down to just two residents.

Key to bringing out the subtleties of these two case studies has been a continuous dialogue between archaeological and documentary sources that has made it possible to foreground aspects that showed up in only one of the sources. A good example is the role of legal changes and their impact on population dynamics and settlement organization. At Ventarola, this has brought to light strong connections between depopulation, abandonment of agro-forestry-pastoral activities and forms of collective management.

At Perlezzi, by contrast, the end of multiple use of environmental resources did not seem to have particular consequences for sharing resources. As at Ventarola, the intensification of cattle breeding strictly related to the need to combine agricultural and animal husbandry activities - perhaps to provide manure for new terraces? At Perlezzi, this happened however in the framework of collective appropriation of the commons, which on the one hand reduced their extent, but on the other hand reinforced the 
shared management of resources. Archaeologically, this could be traced through the irrigation networks, including the necessary agreements for its use, and the proximity of casoni, or rural shelters, to the terraces. The resulting new type of monticazione, or short-distance transhumance, and reorganization of casoni have been noted throughout eastern Liguria between the eighteenth and nineteenth centuries.

The different trajectories of the two villages have resulted in a number of notable contrasts today. The commons of Ventarola have not only been decimated since the end of the nineteenth century, but what remains is also mostly abandoned today. The commons of Perlezzi, by contrast, are thriving: they are the largest in the municipality of Borzonasca, and one of the best-preserved ones in the whole of the Ligurian Apennines. ${ }^{3}$ Whereas in Ventarola, the organization of the village does not seem to suggest any particular-shared place, the collective activities and shared management of the environmental resources in Perlezzi seem to be key to its continuity and well-being. Both the irrigation system and animal husbandry continue to represent the importance co-shared environmental resources and remain the way through which collective and individual interests are reconciliated.

The case of Perlezzi demonstrates that it was precisely the maintenance of collective use rights and shared practices that guaranteed continuity in the management of these lands and contributed towards the preservation of pastoral spaces (the commons) and irrigated terraces and associated constructions. Beyond the two case studies, this is a pattern that has been noted elsewhere, too, as there are many places where the sale of common land and the loss of collective management were more intense, and where depopulation and abandonment impacted more severely as a result. Wherever collective forms of management of environmental resources were maintained, management of resources was by contrast preserved and rural depopulation was much less marked (e.g. Agrawal, Gibson 2001; Lagomarsini 2004; cf. De Moore, Shaw-Taylor, and Warde 2002).

Archaeological research can not only attest to the sustainability of historical agricultural practices (Guttmann-Bond 2010), but it also offers an opportunity to appreciate the material consequences of their abandonment - as we have seen at Ventarola. The case of Perlezzi highlights on the contrary the fragility of rural heritage and shows how archaeology may contribute to planning and managing rural areas. It also underscores the hidden social dimensions of the landscape and draws attention to the importance of social values.

In Perlezzi, the channel of the aqueduct runs nowadays underground in several places (especially inside the settlement), and it, therefore, does not require much maintenance. For centuries this construction was the material expression of the claim of use-rights for water and of the links between individuals, the community and material culture. With water supply regulated by a tap which can be opened and closed, this relationship is somehow 'dematerialized', so it can be 'forgotten'. The loss of technical knowledge required to manage the aqueduct is thus correlated with the degradation of the construction itself and its evident effects on the stability of slopes and the entire system. The role of vegetable gardens in Perlezzi and their irrigation is also a sign of the care dedicated to the place and to the possession of spaces both cultivated and inhabited. The underground ducting, together with its possible effects, makes clear, once again, the hidden social dimension of the environmental management of rural heritage. It shows how the legal dimensions can assist archaeological research to reflect on the importance of these social values and to find useful elements to reconciliate the 'preservation' attempts of central administrations with specific local practices.

\section{Notes}

1. Regione Liguria, Rapporto sullo Stato delle Foreste della Liguria 2011-2013. 
2. Minute di Campagna (1818); Gran Carta degli Stati Sardi di Terraferma, F. LXVIII (ed. 1854); Tavoletta Istituto Geografico Militare, F. 83NE, Favale di Malvaro (1937); Carta Tecnica Regionale a stampa, fogli 214160,214120 e 215090 , riprese aeree $(1973 ; 1990)$. For these sources and further references, see Cevasco (2007). For Ventarola, see Stagno (2018, 79-84).

3. Perlezzi preserves 403 ha of common lands, which is significantly more than other villages, such as Caregli (40 ha) or Caroso (14 ha). Source: Agenzia del Territorio, Genova (year in which data were recorded 2004, year of enquiry 2011). The total extension of lands in the municipality of Borzonasca is around $40 \mathrm{~km}^{2}$.

\section{Acknowledgments}

Fieldwork was carried out under the aegis of the Laboratory of Archaeology and Environmental History (LASA). This study was supported by the University of Genova as part of the projects Perimetri d'acqua. Storia e Archeologia di una risorsa (2007-2008) and Storia e Archeologia della Società rurale (2009-2013); by the Parco Naturale Regionale dell'Avento within the project Parco dell'Aveto e Rete Natura 2000: boschi e biodiversità; and finally by the Marie Curie Actions of the European Union's Seventh Framework Programme (FP7/2007-2013) under REA grant agreement $n^{\circ} 630095$ (2014-2017). I would like to thank Maite Iris García Collado and Eugene Costello for language assistance. I am especially grateful to the anonymous peer reviewers and to Peter van Dommelen for their suggestions and important comments. However, any errors are my only responsibility.

\section{Disclosure statement}

No potential conflict of interest was reported by the author.

\section{Notes on contributor}

Anna Maria Stagno is a post-medieval and rural archaeologist. She has done research as Senior Research Fellow at the University of Durham, at the University of Italian Switzerland - Laboratory of History of the Alps, and as Marie Curie IE Fellow at the University of the Basque Country with the project ARCHIMEDE on the archaeology of commons in southern Europe. She is the PI of the ERC Stg 2019 project ANTIGONE - Archaeology of sharing practices. The marginalisation of European mountains (18th-21st). She is Institute of Advanced Studies Fellow at the University of Durham for the a.y. 2020/2021. Her last monograph is on the Rural archaeology of Ligurian Apennines between 16th-21th c. (All'Insegna del Giglio, 2018). Her research interest are history and archaeology of European rural societies, the historical systems of environmental resources management, with particular reference to sharing practices and commons, and the contribution of research for the construction of a sustainable future for European rural areas.

\section{ORCID}

Anna Maria Stagno (D) http://orcid.org/0000-0003-2456-337X

\section{References}

Agnoletti, M., ed. 2013. Italian Historical Rural Landscapes. Cultural Values for the Environment and Rural Development. Dordrecht: Routledge.

Agnoletti, M., and F. Emanueli, eds. 2016. Biocultural Diversity in Europe. London: Springer.

Agrawal, A., and C. C. Gibson, eds. 2001. Communities and the Environment. Ethnicity, Gender and the State in Community-Based Conservation. New Bruswick: Rutgers University Press.

Andrén, A. 1998. Between Artifacts and Texts. Historical Archaeology in Global Perspective. New York: Springer. Angelucci, D. E., L. Casagrande, A. Colecchia, and M. Rottoli, eds. 2013. Apsat 2. Paesaggi d'altura del Trentino. Evoluzione naturale e aspetti culturali. Arsiero: Società Archaeologica Padana. 
Biagini, M., and M. Milanese. 1998. "Archeologia e storia di un "alpeggio" dell'Appennino ligure orientale: i Casoni della Pietra nella valle Lagorara (Maissana, SP) (XVII-XX sec.)." Archeologia Postmedievale 2: 9-54.

Bille, E., M. Conesa, and R. Viader. 19 2007. "L'appropriation des Espaces Communautaires dans l'Est de éyrénées Médiévales et Modernes: Enquête sur les Cortals." In Les espaces collectifs dans les campagnes XleXXIe siècle, edited by P. Charbonnier, P. Courturier, A. Follain, and P. Fournier, 177-192. Clermont: Presses Universitaires Blaise Pascal.

Carrer, F. 2017. "Interpreting Intra-site Spatial Patterns in Seasonal Contexts: An Ethnoarchaeological Case Study from the Western Alps." Journal of Archaeological Method and Theory 24: 303-327.

Cevasco, R. 2007. Memoria verde. Nuovi spazi per la geografia. Reggio Emilia: Diabasis.

Cevasco, R., ed. 2013. La Natura della Montagna. Studi in Ricordo di Giuseppina Poggi. Sestri Levante: Oltre edizioni.

Clark, J., J. Darlington, and G. Fairclough. 2004. Using Historic Landscape Characterisation. North Yorkshire: English Heritage \& Lancashire County Council.

Collis, J., M. Pearce, and F. Nicolis, eds. 2016. Summer Farms: Seasonal Exploitation of the Uplands from Prehistory to the Present. Sheffield: J. R. Collis Publications.

Dalglish, C. 2003. Rural Society in the Age of Reason: An Archaeology of the Emergence of Modern Life in the Southern Scottish Highlands. New York: Plenum/Kluwer.

De Moore, M., L. Shaw-Taylor, and P. Warde, eds. 2002. The Management of Common Land in North West Europe, C. 1500-1850. Turnhout: Brepols.

Fairclough, G., and A. Wigley. 2006. "Historic Landscape Characterisation: An English Approach to Landscape Understanding and the Management of Change." In Landscapes as Cultural Heritage in the European Research, Proceedings of COST A27 Workshop, edited by M. R. Del Àrbol and A. Orejas, 87-106. Madrid: University of Madrid.

Forbes, H. 2008. Meaning and Identity in a Greek Landscape. An Archaeological Ethnography. Nottingham: University of Nottingham.

Galop, D., and N. Catto, eds. 2014. "Environmental History of European High Mountain." Quaternary International 353: 1-266. doi:10.1016/j.quaint.2014.10.040.

Gambi, L. 1976. "La casa contadina." In Storia d'Italia 6 (Atlante), edited by L. Gambi and G. Bollati, 479-505. Torino: Einaudi.

Gilchrist, R. 2009. "Medieval Archaeology and Theory: A Disciplinary Leap of Faith." In Reflections: 50 Years of Medieval Archaeology, 1957-2007, edited by R. Gilchrist and A. Reynolds, 385-408. Leeds: Society for Medieval Archaeology.

Grendi, E. 1993. Storia di una storia locale: l'esperienza ligure: 1792-1992. Venezia: Marsilio.

Grove, A. T., and O. Rackham. 2001. The Nature of Mediterranean Europe: An Ecological History. New Haven: Yale University Press.

Guttmann-Bond, E. 2010. "Sustainability Out of the Past: How Archaeology Can Save the Planet." World Archaeology 42: 355-366. doi:10.1080/00438243.2010.497377.

Horning, A., and M. Palmer, eds. 2009. Crossing Paths or Sharing Tracks? Future Directions in the Archaeological Study of Post-1550 Britain and Ireland. Suffolk: Boydell Press.

Ingold, T. 2000. "The Temporality of the Landscape." World Archaeology 25: 152-174. doi:10.1080/ 00438243.1993.9980235.

Kirby, K., and C. Watkins, eds. 1998. The Ecological History of European Forests. Wallingford: CAB International.

Lagomarsini, S. 2004. "Urban Exploitation of Common Rights: Two Models of Land Use in the Val di Vara." In Ligurian Landscapes: Studies in Archaeology, Geography and History in Memory of Edoardo Grendi, edited by R. Balzaretti, M. Pearce, and C. Watkins, 179-188. London: Accordia Research Institute.

Le Couédic, M., C. Rendu, D. García Casas, E. Gassiot Ballbé, C. Calastrenc, I. C. Conte, A. Forto, et al. 2015. "Comparer et modéliser les sites, les territoires et les systèmes pastoraux pyrénéens dans la diachronie: présentation et premiers résultats du projet collaboratif DEPART." In Pays pyrénéens et environnement, edited by P. Debofle and J. C. Sanche, 321-338. Paris: Société Ramond.

Maggi, R., C. Montanari, and D. Moreno, eds. 2002. "Atti del Seminario Internazionale L'approccio storico ambientale al Patrimonio rurale delle aree protette." Archeologia Postmedievale 6: 9-214.

Martín Civantos, J. M. 2011. "The Archaeology of Irrigated Spaces in South-East Spain during the Medieval Period." In Food in the Medieval Rural Environment: Processing, Storage, Distribution of Food, edited by J. Klápšte and P. Sommer, 11-29. Turnhout: Brepols. 
Meyer, W. J., and C. L. Crumley. 2011. "Historical Ecology: Using What Works to Cross the Divide." In Atlantic Europe in the First Millennium BC: Crossing the Divide, edited by T. Moore and L. Armada, 109-134. Oxford: Oxford University Press.

Mientjes, A. C. 2008. Paesaggi pastorali. Studio etnoarcheologico sul pastoralismo in Sardegna. Cagliari: CUEC.

Mientjes, A. C., M. Pluciennik, and E. Giannitrapani. 2002. "Archaeologies of Recent Rural Sicily and Sardinia: A Comparative Approach." Journal of Mediterranean Archaeology 15 (2): 139-166.

Molinari, C., and C. Montanari. 2016. "Interdisciplinary Approach for Reconstructing an Alder-Based Historical Agricultural Practice of the Eastern Ligurian Apennines (NW Italy)." Environmental Archaeology 21: 31-44. doi:10.1179/1749631414Y.0000000056.

Moneta, V. and Parola, C. eds. 2014. Oltre la rinaturalizzacione. Studi di ecologia storica per la riqualificazione dei paesaggi rurali. Sestri Levante: Oltre Edizioni.

Moreno, D. 1976. in Moreno D. and Quaini M. 1976. “Per Una Storia Della Cultura Materiale.” Quaderni Storici 31: 5-37. Moreno, D. 1990. Dal documento al Terreno. Storia e archeologia dei sistemi agro-silvo-pastorali. Bologna: II Mulino.

Moreno, D., R. Cevasco, S. Bertolotto, and G. Poggi. 1998. "Historical Ecology and Post-medieval Management Practices in Alder Woods (alnus Incana (L.) Moench) in the Northern Apennines, Italy." In The Ecological History of European Forests, edited by K. Kirby and C. Watkins, 185-201. Wallingford: CAB International.

Moreno, D., and O. Raggio. 1990. "The Making and Fall of an Intensive Pastoral Land-Use-System. Eastern Liguria, 16th-19th Centuries." Rivista Di Studi Liguri 56: 193-217.

Quaini, M., and D. Moreno, eds. 1973. "Geografie del popolamento." Quaderni Storici 24: 603-924.

Rackham, O. 1976. Trees and Woodland in the British Landscape. London: J.M. Dent \& Sons.

Raggio, O. [1990] 2018. Feuds and State Formation, 1550-1700. The Backcountry of the Republic of Genoa. Basingstoke: Palgrave Macmillan.

Relaki, M., and D. Catapoti, eds. 2013. An Archaeology of Land Ownership. London: Routledge.

Rendu, C. 2003. La Montagne d'Enveig, un estive pyréneénne dans la longue durée. Perpignan: Ed. du Trabucaire.

Rendu, C., C. Calastrenc, M. Le Couédic, and A. Berdoy, eds. 2016. Estives d'Ossau. 7000 ans de pastoralisme dans les Pyrénées. Toulouse: Le Pas d'Oiseau éditions.

Rotherham, I. D., ed. 2013. Cultural Severance and the Environment. The Ending of Traditional and Customary Practice on Commons and Landscapes Managed in Common. Dordrecht: Springer.

Salvi, G. 1981. "Continuità e cambiamento in una società dell'Appennino: Bertassi nei secoli XIX e XX." Quaderni Storici 46: 131-152.

Stagno, A. M. 2016. "Seasonal Settlements and Husbandry Resources in Ligurian Apennines (17-20 C.)." In Summer Farms: Seasonal Exploitation of the Uplands from Prehistory to the Present, edited by J. Collis, M. Pearce, and F. Nicolis, 67-88. Sheffield: J. R. Collis Publications.

Stagno, A. M. 2018. Gli spazi dell'archeologia rurale. Risorse ambientali e insediamenti nell'appennino ligure tra XV e XXI secolo. Firenze: All'Insegna del Giglio.

Stagno, A. M., and V. Tigrino. 2012. "Beni comuni, proprietà privata e istituzioni: un caso di studio dell'Appennino ligure (XVII-XX secolo)." Archivio Scialoja-Bolla 1 (2012): 261-302.

Svensson, E., and E. Costello, eds. 2018. Historical Archaeologies of Transhumance Across Europe. London: Routledge.

Tarlow, S. 2007. The Archaeology of Improvement in Britain, 1750-1850. Cambridge: Cambridge University Press.

Thompson, E. P. 1993. Customs in Common. Studies in Traditional Popular Culture. New York: New Press.

Turner, S. 2006. “Historic Landscape Characterisation: A Landscape Archaeology for Research, Management and Planning." Landscape Research 31-4: 385-398. doi:10.1080/01426390601004376.

Vaccarezza, C. 2011. Paesaggi rurali tra storia delle risorse e morfologia sociale. PhD diss., Università di Genova. Vecchio, B., P. Piussi, and M. Armiero. 2002. "L'uso del bosco e degli incolti." In Storia dell'agricoltura italiana III. L'età contemporanea, edited by R. Cianferoni, Z. Ciuffoletti, and L. Rombai, 128-216. Firenze: Polistampa.

Viader, R., and C. Rendu, eds. 2014. Cultures temporaires et féodalité. Les rotations culturales et l'appropriation du sol dans l'Europe médiévale et moderne. Toulouse: Presses Universitaires du Mirail.

Walsh, K. J., and F. Mocci. 2016. "Driving Forces and Variability in the Exploitation of a High-Altitude Landscape from the Neolithic to Medieval Periods in the Southern French Alps." In Summer Farms: Seasonal Exploitation of the Uplands from Prehistory to the Present, edited by J. Collis, M. Pearce, and F. Nicolis, 183-202. Sheffield: J. R. Collis Publications. 